\title{
PREVALENCE AND CHARACTERIZATION OF SHIGATOXIGENIC ESCHERICHIA COLI IN BROILER BIRDS IN MYMENSINGH
}

\author{
M. M. Mamun ${ }^{1}$, M. S. Parvej ${ }^{2}$, S. Ahamed ${ }^{1}$, J. Hassan ${ }^{1}$, K. H. M. N. H. Nazir ${ }^{1}$, Y. Nishikawa ${ }^{2}$ and \\ M. T. Rahman ${ }^{1 *}$ \\ ${ }^{1}$ Department of Microbiology and Hygiene, Bangladesh Agricultural University, Mymensingh-2202, \\ Bangladesh; ${ }^{2}$ Osaka City University Graduate School of Human Life Science, Osaka 558-8585, Japan
}

\begin{abstract}
Shigatoxigenic Escherichia coli (STEC) are major food-borne pathogens. They transmit to human through contaminated meat and meat products of animals and poultry, and frequently associated with various types of human illness including haemolytic uremic syndrome. This preliminary study showed the prevalence of STEC in 60 cloacal swab samples of live healthy broiler chickens collected randomly when sold at a wholesale market in Mymensingh district of Bangladesh. Isolation and identification of E. coli was carried out using Eosin Methylene Blue (EMB) agar media and 16S rRNA gene specific polymerase chain reaction (PCR). Among the 60 samples, $49(81.67 \%)$ were found positive to E. coli. These E. coli isolates were screened for the detection of STEC by PCR using $s t x 1$ and st $x 2$ gene specific primers. Among the 49 positive samples, 5 $(10.20 \%)$ were found positive for $s t x 1$ gene, and $26(53.06 \%)$ were positive for stx2 gene. In addition, $6(12.24 \%)$ isolates were found positive to both $s t x 1$ and stx 2 genes, and the remaining $12(22.46 \%)$ were negative. The high prevalence of STEC in the broiler chicken alarms the public health impact as the people are always in close contact with these live broiler chickens in the open market as well as processing of meat at home before cooking. However, further studies are required to uncover the major source(s) for the transmission of STEC to human in rural Bangladesh.
\end{abstract}

Keywords: Shigatoxigenic E. coli, prevalence, characterization, cloacal swab, broiler

\section{INTRODUCTION}

In Bangledesh, due to almost assured and quick return in a relatively short period of time, poultry rearing is considered superior to the other sectors in agriculture. The poultry industry comprising of commercial poultry with broiler and layers plays an important role in the development of economy in Bangladesh. In Bangladesh, the total chicken population is about 259.79 million (Bangladesh Economic Review, 2014). The sector has already proved itself as a potential income generation and poverty alleviation as well as improving human nutrition through the supply of meat and eggs to their daily life and also contributes $2.79 \%$ GDP (BBS, 2008).

Poultry sectors across the globe are affected by various bacterial pathogens including avian pathogenic Escherichia coli (APEC) (Bélanger et al., 2011). Among these APEC, some produce shiga toxin-producing E. coli (STEC) and also known as verotoxin producing E. coli (VTEC) causing disease in humans and animals. The common feature of STEC is the production of shiga toxins (Stx) that are considered to be the major virulence factors.

There are two major groups of shiga toxins: Stx1 and Stx2, expressed by stx1 and stx2 located in the genome of lambdoidprophages (Friedman and Court, 2001). The most common sources for shiga toxin are the bacteria Shigella dysenteriae and the STEC (Beutin et al., 2006; Spears et al., 2006). STEC are becoming an ever increasing problem as an etiological agent of food-borne gastrointestinal disease. Stx is characterized by the cytotoxicity due to disruption of protein synthesis within host cells. STEC strains are capable of causing human illness, especially haemorrhagic colitis, bloody diarrhoea and haemolytic uraemic syndrome (HUS). Although most sporadic cases and outbreaks have been reported from developed countries, human infections also have been described in Latin America, India and other developing countries (Kaddu-Mulindw et al., 2001; Leelaporn et al., 2003). STEC may be transmitted through faecal material contaminated water or food, or through direct contact with animals or persons (Paton and Paton, 2002). Several works have been done in Bangladesh regarding the isolation and molecular characterization of shiga toxin producing E. coli from the intestinal contents and meat of cattle, diarrheic human patients and from the intestinal contents and meat of cattle diarrheic human patients,

*Corresponding e-mail address: tanvirahman@bau.edu.bd 
M. M. Mamun and others

the environment by several researchers (Hossain et al., 2011; Islam et al., 2008; Alam et al., 2006). To the best of our knowledge, no work has yet conducted for the isolation and molecular characterization of STEC from cloacal swab sample of broiler birds in Bangladesh. This study was undertaken to determine the occurrence of STEC in cloacal swab samples of healthy broiler chickens sold in rural markets, and evaluation of their public health significance.

\section{MATERIALS AND METHODS}

\section{Sample collection}

The swab samples from cloacae $(n=60)$ were collected randomly from different local live broiler bird markets of Mymensingh district, Bangladesh, following a convenient sampling method. Properly sterile cotton buds were used for the collection of swab samples. After collection, the swab was instantly transferred to nutrient broth and kept in ice box. The swab samples were transported to the Bacteriology Laboratory at the Department of Microbiology and Hygiene, Bangladesh Agricultural University, Mymensingh.

\section{Cultural and biochemical examination}

Overnight incubation of the nutrient broth containing swab samples was done at $37^{\circ} \mathrm{C}$. Then samples from the nutrient broth were cultured on Eosin Methylene Blue (EMB) agar medium (Zadik et al., 1993). One colony from each EMB plate that showed metallic sheen on EMB agar was subjected to sugar (dextrose, maltose, lactose, sucrose, and mannitol) fermentation, Methyl Red-Voges Proskauer (MR-VP) and indole production tests following the procedures described by Nazir et al. (2005) and Elafify et al. (2016).

\section{DNA Extraction and molecular identification}

DNA was obtained from the isolates using boiling method (Queipo-Ortun et al., 2008). In brief, $100 \mu \mathrm{lde}-$ ionized water was taken into an eppendrof tube. A pure bacterial colony from overnight culture on $37^{\circ} \mathrm{C}$ of $\mathrm{EMB}$ agar was properly mixed with the de-ionized water. The tube was then transferred to boiling water and boiled for 10 minutes then immediately kept on ice for 10 minutes and then centrifuged at 10,000 rpm for 10 minutes. Supernatant was collected and used as DNA template. The DNA sample was kept in $-20^{\circ} \mathrm{C}$ until used.

The isolated organisms that were suspected to be E. coli by their cultural and biochemical characteristics were confirmed as $E$. coli by PCR with primers specific to $E$. coli $16 \mathrm{~S}$ rRNA gene (Table 1). DNA extracted from known E. coli was sued as PCR positive control while water was used as the negative control. PCR was performed following the procedure described by Hassan et al. (2014). A $25 \mu 1$ reaction contained 1x Taq Polymerase PCR master mix and $0.4 \mu \mathrm{M}$ final concentration of each primer. Electrophoresis of the PCR products was done using $2 \%$ agarose gel. After electrophoresis, the gel was stained for 10 minutes in ethidium bromide for visualization in UV Tran-illuminator.

Isolates that were found positive for $E$. coli 16 SrRNA genes were further screened for st 1 and st $x 2$ by PCR with primers (Table 1) specific for E. coli stx 1 and stx2 genes (Talukdar et al., 2013) with slight modification. There was $25 \mu \mathrm{l}$ reaction containing 1x Taq Polymerase PCR master mix and $0.4 \mu \mathrm{M}$ final concentration of the primers (stx 1 or stx2). Thermal profile for the detection of stx 1 and stx 2 consisted of an initial denaturation at $94^{\circ} \mathrm{C}$ for $5 \mathrm{~min}$, followed by denaturation at $94^{\circ} \mathrm{C}$ for $1 \mathrm{~min}$, annealing for $1 \mathrm{~min}\left(61^{\circ} \mathrm{C}\right.$ for $\operatorname{st} x 1,59^{\circ} \mathrm{C}$ for stx 2$)$ and extension at $72^{\circ} \mathrm{C}$ for $1 \mathrm{~min}$ (total 30 cycles), with a final extension at $72^{\circ} \mathrm{C}$ for $5 \mathrm{~min}$. PCR amplification was performed using a thermo cycler (Eppendorf Personal, Germany). Appropriate PCR positive (DNA from STEC) control and non-template negative control were also used in each PCR reactions.

Table 1. List of primers used for the detection of E. coli $16 \mathrm{~S}$ rRNA gene, st 1 and st $x 2$ genes

\begin{tabular}{llcc}
\hline Primer Name & \multicolumn{1}{c}{ Sequence (5' - 3') } & Amplicon Size (bp) & Target gene \\
\hline ECO-1 & GACCTCGGTTTAGTCACAGA & 585 & 16 rRNA \\
ECO-2 & CACACGCTGACGCTGACCA & & stx 1 \\
\hline stx 1F & CAC AAT CAG GCG TCG CCA GCG CAC TTG CT & 606 & $s t x 2$ \\
stx 1R & TGT TGC AGG GAT CAG TCG TAC GGG GAT GC & & \\
\hline stx 2F & CCA CAT CGG TGT CTG TTA TTA ACC ACA CC & 372 & \\
stx 2R & GCA GAA CTG CTC TGG ATG CAT CTC TGG TC & & \\
\hline
\end{tabular}




\section{RESULTS AND DISCUSSION}

This study revealed the presence of $E$. coli in $81.67 \%(49 / 60)$ cloacal swabs collected from healthy broiler birds (Table 2). The overall prevalence of this study supported the findings of Jakaria et al. (2012), who described a prevalence of $78.86 \%$ in the apparently healthy chicken in Myemnsingh district. In another study, Roy et al. (2012) isolated $E$. coli from 52\% samples comprising internal organs of broilers.

These $49 \mathrm{E}$. coli (one isolate per sample) were examined further for the presence of st $x 1$ and st $x 2$ genes by PCR to identify STEC. Among them, $5(10.20 \%)$ isolates were found positive for stx 1 alone (Figure 1), while 26 $(53.06 \%)$ for stx 2 alone (Table 2 and Figure 2). In addition, $6(12.24 \%)$ were found positive for both stx 1 and st $x 2$. On the other hand, the remaining $12(24.28 \%)$ isolates were found as non-STEC, since they were found negative for both stxl and stx 2 genes (Table 2). Supporting our present findings, low prevalence of shiga-toxin was also reported by Rehman et al. (2014).

Contaminated meat is considered as the major source for the outbreak of STEC in human. The occurrence of STEC in the broiler chicken sold in retail market is alarming to the rural public health of Bangladesh as they are always in close contact with these broiler chickens in the wholesale market and /or domestic meat processing. So far, this is the first report on the occurrence of STEC in broiler chicken in Bangladesh, and further studies are required to uncover the major source(s) for the transmission of STEC to human in Bangladesh.

Table 2. Prevalence of shigatoxigenic E. coli in cloacal samples

\begin{tabular}{cccccc}
\hline \multirow{2}{*}{$\begin{array}{c}\text { Total number } \\
\text { of samples }\end{array}$} & 16S rRNA gene & \multicolumn{4}{c}{ Number of PCR positive samples (N=49) } \\
\cline { 3 - 6 } & & $s t x 1$ & $s t x 2$ & Both stx 1 and $s t x 2$ & Non-STEC \\
\hline 60 & $49(81.67 \%)$ & $5(10.20 \%)$ & $26(53.06 \%)$ & $6(12.24 \%)$ & $12(24.28 \%)$ \\
\hline
\end{tabular}

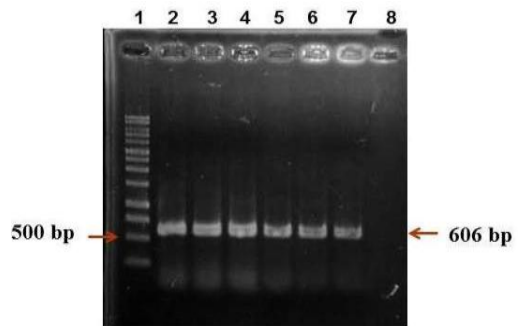

Figure 1. PCR based detection of stxl gene. Lane 1: $1 \mathrm{~kb}$ DNA marker; lane 2 to 6: E. coli isolates; Lane 7: Positive control, Lane 8: Negative control

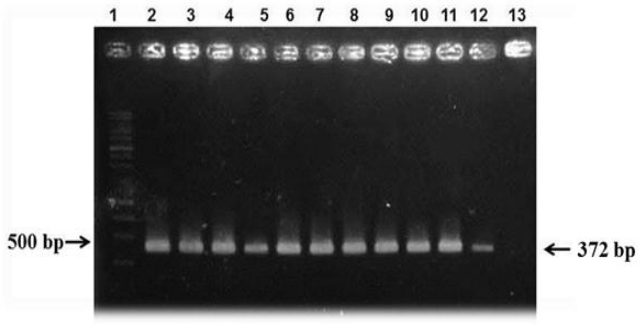

Figure 2. PCR based detection of stx 2 gene. Lane 1: $1 \mathrm{~kb}$ size DNA marker; lane 2 to 11: E. coli isolates; Lane 12: Positive control, Lane 13: Negative control

\section{CONCLUSIONS}

The STEC has been successfully detected by PCR from apparently healthy broiler chicken sold in retail market in Mymensingh, Bangladesh. The high prevalence of STEC in the broiler chicken has great public health significance since these birds can be a potential source for human STEC infection.

\section{ACKNOWLEDGEMENTS}

The authors extend their sincere thanks to Bangladesh Agricultural University and Bangladesh Agricultural Research Council (BARC) for financial supports.

\section{REFERENCES}

1. Alam M, Hasan NA, Ahsan S, Pazhani GP, Tamura K, Ramamurthy T, Gomes DJ, Rahman SR, Islam A, Akhtar F, Shinoda S, Watanabe H, Faruque SM and Nair GB (2006). Phenotypic and molecular characteristics of Escherichia coli isolated from aquatic environment of Bangladesh. Microbiology and Immunology 50: 359-370.

2. BBS (2008). Report on the Bangladesh Livestock Survey 2008-09. Bangladesh Bureau of Statistics, Ministry of Planning, Government of the People's Republic of Bangladesh, Dhaka. 
3. Bangladesh Economic Review (2014). http://www.mof.gov.bd/en/budget/15_16/ber/bn/Chapter-7\% 20(Bangla2015) \%20final.pdf.

4. Bélanger L, Garenaux A, Harel J, Boulianne M, Nadeau E and Dozois CM (2011). Escherichia coli from animal reservoirs as a potential source of human extra intestinal pathogenic E. coli. FEMS Immunology and Medical Microbiology 62: 1-10.

5. Beutin L, Geier D, Zimmeronann S, Aleksic S, Gille-spie HA and Whittam TS (1997). Epidemiological relatedness and clonal types of natural populations of E. coli strains producing shiga toxin in separate population of cattle and sheep. Applied and Environmental Microbiology 63: 2175-2180.

6. Elafify M, Elsherbini M, Abdelkhalek A and Al-Ashmawy M (2016). Prevalence and molecular characterization of enteropathogenic Escherichia coli isolated from table eggs in Mansoura, Egypt. Journal of Advanced Veterinary and Animal Research 3: 1-7.

7. Friedman D and Court D (2001). Bacteriophage lambda: alive and well and still doing its thing. Current Opinion in Microbiology 4: 201-207.

8. Hassan J, Parvej MS, Rahman MB, Khan MSR, Rahman MT, Kamal T and Nazir KHMNH (2014). Prevalence and characterization of Escherichia coli from rectal swab of apparently healthy cattle in Mymensingh, Bangladesh. Microbes and Health 3: 12-14.

9. Hossain Z, Sultana P, Deb S and Ahmed MM (2011). Multidrug resistance in large-plasmid-associated presumptive enterohaemorrhagic Escherichia coli isolated from contaminated lake water. Bangladesh Journal of Microbiology 28: 33-40.

10. Islam MA, Mondol AS, Boer ED, Beumer RR, Zwietering MH, Talukder KA and Heuvelink AE (2008). Prevalence and genetic characterization of shiga toxin-producing Escherichia coli isolates from slaughtered animals in Bangladesh. Applied and Environmental Microbiology 74: 5414-5421.

11. Jakaria ATM, Islam MA and Khatun MM (2012). Prevalence, characteristics and antibiogram profiles of Escherichia coli isolated from apparently healthy chickens in Mymensingh, Bangladesh. Microbes and Health 1: 27-29.

12. Kaddu-Mulindw DH, Aisu T, Gleier K, Zimmermann S and Beutin L (2001). Occurrence of shiga toxin-producing Escherichia coli in fecal samples from children with diarrhea and from healthy zebu cattle in Uganda. International Journal of Food Microbiology 66: 95-101.

13. Leelaporn A, Phengmak M, Eampoklap B, Manatsathit S, Tritilanunt S, Siritantikorn S, Nagayama K, Iida T, Niyasom C and Komolpit P (2003). Shigatoxin- and enterotoxin-producing Escherichia coli isolated from subjects with bloody and non-bloody diarrhea in Bangkok, Thailand. Diagnostic Microbiology and Infectious Disease 46:173-180.

14. Nazir KHMNH, Rahman MB, Nasiruddin KM, Akhtar F, Khan MFR and Islam MS (2005). Antibiotic sensitivity of Escherichia coli isolated from water and its relation with plasmid profile analysis. Pakistan Journal of Biological Sciences 8: 1610-1613.

15. Paton AW and Paton JC (2002). Direct detection and characterization of shiga toxigenic Escherichia coli by multiplex PCR for stx1, stx2, eae, ehxA, and saa. Journal of Clinical Microbiology 40: 271-274.

16. Queipo-Ortun MI, Colmenero JDD, Macias M, Bravo MJ and Morata P (2008). Preparation of bacterial DNA template by boiling and effect of immunoglobulin $G$ as an inhibitor in real-time PCR for serum samples from patients with brucellosis. Clinical and Vaccine Immunology 15: 293-296.

17. Rehman MU, Rashid M, Sheikh JA, Bhat MA (2014). Molecular epidemiology and antibiotic resistance pattern of Enteropathogenic Escherichia coli isolated from bovines and their handlers in Jammu, India. Journal of Advanced Veterinary and Animal Research 1: 177-181.

18. Roy SR, Rahman MB, Hassan J and Nazir KHMNH (2012). Isolation and identification of bacterial flora from internal organs of broiler and their antibiogram studies. Microbes and Health 1: 72-75.

19. Spears KJ, Roe AJ and Gally DL (2006). A comparison of enteropathogenic and enterohaemorragic E. coli pathogenesis. FEMS Microbiology Letters 255: 187-202.

20. Talukdar PK, Rahman M, Rahman M, Nabi A, Islam Z, Hoque M, Endtz HP and Islam MA (2013). Antimicrobial resistance, virulence factors and genetic diversity of Escherichia coli isolates from household water supply in Dhaka, Bangladesh. PloS ONE 8: e61090.

21. Zadik PM, Chapman PA and Siddons CA (1993). Use of tellurite for the selection of verocytotoxigenic Escherichia coli 0157. Journal of Medical Microbiology 39: 155-158. 